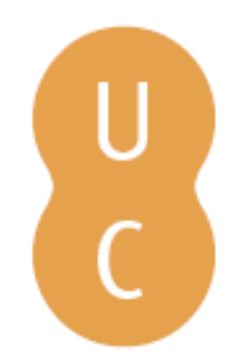

\title{
nommalina
}

\section{Un pueblo que mantiene viva su memoria nunca muere Versión libre de Las troyanas de Eurípides}
Autor(es):
Grimoldi, María Inés
Publicado por: Imprensa da Universidade de Coimbra; Annablume
URL
persistente:
URI:http://hdl.handle.net/10316.2/40920
DOI:
DOI:https://doi.org/10.14195/978-989-26-1298-0_14
Accessed : $\quad$ 26-Apr-2023 06:58:44

A navegação consulta e descarregamento dos títulos inseridos nas Bibliotecas Digitais UC Digitalis, UC Pombalina e UC Impactum, pressupõem a aceitação plena e sem reservas dos Termos e Condições de Uso destas Bibliotecas Digitais, disponíveis em https://digitalis.uc.pt/pt-pt/termos.

Conforme exposto nos referidos Termos e Condições de Uso, o descarregamento de títulos de acesso restrito requer uma licença válida de autorização devendo o utilizador aceder ao(s) documento(s) a partir de um endereço de IP da instituição detentora da supramencionada licença.

Ao utilizador é apenas permitido o descarregamento para uso pessoal, pelo que o emprego do(s) título(s) descarregado(s) para outro fim, designadamente comercial, carece de autorização do respetivo autor ou editor da obra.

Na medida em que todas as obras da UC Digitalis se encontram protegidas pelo Código do Direito de Autor e Direitos Conexos e demais legislação aplicável, toda a cópia, parcial ou total, deste documento, nos casos em que é legalmente admitida, deverá conter ou fazer-se acompanhar por este aviso.

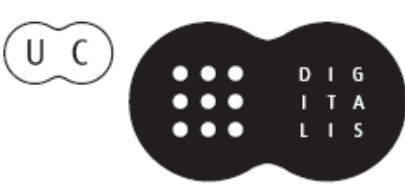




\section{O Livro do Tempo: \\ Escritas e reescritas}

\section{Teatro Greco-Latino e sua recepção II}

Maria de Fátima Silva, Maria do Céu

Fialho \& José Luís Brandão (coords.)

IMPRENSA DA UNIVERSIDADE DE COIMBRA 


\title{
UN PUEBLO QUE MANTIENE VIVA SU MEMORIA NUNCA MUERE Versión LIBRE de LAS TROYANAS DE EuRÍPIDES (A people that preserves alive its memory never dies. A free version of Euripides' Trojan Women)
}

\author{
María InÉs Grimoldi (www.inesgrimolditeatro.com.ar) \\ Universidad de Buenos Aires
}

\begin{abstract}
Resumen - El propósito de este trabajo es pensar la relación que el teatro mantiene con la historia y con la memoria desde una perspectiva política, así como también el lugar del intelectual-artista en nuestra contemporaneidad, pero relacionándolo con un pasado donde lo que más cambia es la forma en que se mira.
\end{abstract}

Palabras clave - Eurípides, Las troyanas, Constanza Maral, ...Allá donde fuéramos, representação.

Aвstract - The aim of this article is to consider the relation between theatre, history and memory under a political perspective, as well as the place of the intellectual-artist in contemporaneity, in connection with a past where the most unstable criterium is the way of looking.

Keywords - Euripides, Trojan Women, Constanza Maral, ...Allá donde fuéramos, performance.

Como introducción voy a definir la existencia de dos tipos de teatro político. El primero de ellos, el teatro político propiamente dicho, es aquel que muestra un acontecimiento, que adhiere a la noción de denuncia, que busca la empatía ideológica con el receptor y para lograrlo apela a una estética clara que disminuya el nivel de ruido existente en todo proceso de comunicación. Y el segundo tipo, el teatro meta-político, es aquel que reflexiona, que deconstruye el ejercicio del poder. El teatro, hoy, se ubica en una zona deconstructiva de los mecanismos de lo social. Deconstruye una institución como la familia, o revee la historia desde parámetros distintos.

Esta reflexión surge de una entrevista realizada a la actriz, dramaturga y directora Constanza Maral en relación a su obra ...Allá donde fuéramos versión libre de Las Troyanas de Eurípides. No sólo se hará referencia a la reescritura de la obra y a su representación sino también a la recepción por parte de los espectadores.

El proyecto original iba a ser una ligera adaptación de Las Troyanas de Sartre. Pero se encontró con la dificultad de que provenía de la obra de Eurípides. Y para comprender mejor la historia había que conocer La Ilíada y La Odisea de Homero sino no se llegaba al fondo de la cuestión.

Por otra parte, la autora se encontró frente a dos problemas: primero que para el público, en general, era imposible manejar toda esa cantidad de dioses 
que aparecen en la obra, la gente no entendía de qué se estaba hablando. Y la segunda dificultad fue que no era eso lo que ella quería decir. Lo que más le interesaba de Las troyanas o lo que quería resaltar era que se trataba de un alegato contra las guerras.

Una vez realizado el trabajo de estudio e investigación sobre estos textos (La Ilíada, La Odisea, las versiones de Eurípides y de Sartre) decidió respetar el orden de las escenas de Eurípides y el centro, el corazón de lo que hay en cada una de ellas. Pero trayéndolo a un idioma, a una manera de expresarse que nos represente hoy en día.

En la versión de Eurípides, las mujeres del pueblo que constituyen el coro, comentan, opinan, pero no tienen de ninguna manera el protagonismo que ella les da.

En la versión original aparece Casandra y en esta pieza escuchamos sólo la voz en off. Casandra era llamada "la loca", la negada por su padre, era la que veía y la que alertaba acerca de lo que iba a pasar y no fue escuchada. Fue privada de su libertad y castigada por saber y sobre todo por el saber en una mujer.

También está ausente el personaje de Helena y el de Menelao. Y esto fue una decisión de la autora porque sino, según sus palabras, tendríamos que creer que dos pueblos se han peleado y destruido durante diez años por la belleza de una mujer. Los troyanos tenían un lugar muy importante que era el Estrecho del Elesponto. Es un lugar por donde todos los barcos tenían que pasar y, por ende, para pasar por allí tenían que pagar peaje. Exactamente igual que hoy. Eso también había hecho de Troya una ciudad maravillosa porque era un lugar de fusión de culturas. Entonces se inicia esa guerra, se dice que es porque Menelao quiere recuperar a su mujer y está a punto de hacerlo pero lo que quieren es hacer la guerra, lo que quieren es Troya. Y quedarse con ese paso que es el Estrecho del Elesponto. Y este es un punto importante a resaltar: siempre las guerras se hacen por motivos económicos aunque se intente disfrazarlo. En la entrevista, la autora relaciona estos hechos con las guerras que conocemos en nuestro tiempo (Irak, Afganistán, Libia) y en las excusas que se utilizan en nombre de la libertad para la apropiación de territorios o de riquezas, como en esta época el petróleo. Es uno de los puntos centrales del trabajo de adaptación libre de esta obra de Eurípides: descubrir los mecanismos del poder, los verdaderos motivos de las guerras tanto en la época de Troya como ahora, y reflexionar acerca del rol de la mujer en estos procesos. Por eso la obra intenta con sutilezas lograr un clima atemporal.

Además de la guerra, otro tema importante es la esclavitud de las mujeres que se convierten en botín después de la destrucción de Troya. Y aquí está la diferencia con la obra original. Ya perdieron todo, marido, hijos, riquezas, sólo les queda su propia vida. Y van a ser llevadas como esclavas. Como esclavas sexuales, como esclavas de trabajo. Y además en aquella época era muy prestigioso para el vencedor tener como esclava, por ejemplo a Andrómaca, que había sido la mujer del gran Héctor. Lo importante es quedarse con la prenda, el trofeo de guerra, mujer o madre de un guerrero importante. Estas mujeres no pueden negarse a que las 
lleven. Lo hacen a punta de lanza, Troya es incendiada y destruida. El tema es que en Las troyanas en su versión original estas mujeres se van llorando su vida perdida, su desgracia. En la versión libre que analizamos, toman absoluta conciencia de lo que ha sucedido. En algún momento reconocen no haber estado lo suficientemente atentas mientras algo sucedía y ellas no escuchaban. Entre otras cosas porque nadie podía entrar a Troya. Sus puertas eran inexpugnables. Los griegos utilizan una enorme trampa. Pero son los troyanos los que destruyen su propia puerta para dejar entrar al caballo. Deciden entrarlo desoyendo a Casandra. Y también como señal de paz para que no se iniciara otra vez la guerra. Esta es la responsabilidad de los troyanos en su propia destrucción. Finalmente, estas mujeres entienden que hay algo que no pudieron robarles: su inteligencia, su conciencia, su palabra, su memoria. Entonces van como esclavas, no pueden evitarlo, las arrastran, pero ellas saben a donde. Por eso la obra se llama ...Allá donde fuéramos. Ellas van a hablar, contarán cuál fue su historia, cuál fue su vida, cuál fue su memoria, cuáles fueron sus comidas, cuál era su visión del mundo. Las que no iban como esclavas sexuales iban como institutrices ya que tenían muy buena educación. Van a enseñar a los hijos del enemigo todo lo que significa una guerra, todo lo que se pierde en una guerra, van a mantener viva su memoria y aparecerá, en esos niños o en esos amantes, su versión de los acontecimientos, de la historia. Esta es la diferencia con las versiones anteriores, el protagonismo de estas mujeres que habiéndolo perdido todo deciden no renunciar ni a la palabra, ni a la memoria, ni a su propia historia. Y un pueblo que no pierde su memoria, suceda lo que suceda va a resurgir. Esta es la idea principal de esta versión, el protagonismo femenino, que no es el de Helena sino el de estas mujeres, y dejar en claro cuál es el verdadero motivo de las guerras. Las troyanas son esclavas pero no personajes pasivos. Tienen limitaciones porque están privadas de su libertad, pero pueden cambiar la historia al educar al enemigo o al ser amantes del enemigo. Los hijos de los vencedores van a escuchar una historia diferente a la que les cuenten sus padres. Es la voz de los vencidos que aparece por los márgenes construyendo otro relato.

Con respecto a su representación, la obra se estrenó en marzo del 2010 en el teatro Dandelión y este año vuelve a escena con modificaciones. Estos cambios se harán en relación con la recepción y comentarios del público y críticos. Hay que mencionar que después de la representación, se sirve un vino tinto y otros manjares que nos sumergen en lo dionisíaco que tiene el teatro (según palabras de la autora, esta parte placentera y gozosa no debería obviarse nunca ya que es imprescindible en una representación de este tipo). Además favorece el diálogo con el público y con la crítica generando un ambiente distendido, casi una continuación de la representación o abriendo otra representación.

Para concluir, me formulo las siguientes preguntas: ¿Qué es el pasado?, ¿Cuál es su forma?, ¿Cuáles son los modos de mirar y de reflexionar sobre él?, ¿Cuáles las formas del recuerdo y de la memoria?, ¿Cómo se recuperan?. Estas preguntas plantean problemas que son constitutivos no sólo de la historia sino 
también del arte y de la cultura.

En un contexto en el cual los debates sobre la memoria y el olvido son centrales, la obra de Walter Benjamín (2010) 350 ayuda a esclarecer y reflexionar sobre la memoria y el recuerdo. Memoria y recuerdo expresan en su obra dos nociones a través de las cuales se dirimen dos modos de configuración del mundo. Por eso, la oposición entre memoria y recuerdo se puede traducir en una tensión entre, por un lado, una repetición conmemorativa cercana a cierta voluntad historicista, y por otro, la construcción de un pasado en el límite entre lo individual y lo colectivo. Esta tensión aparece desarrollada en los escritos de Benjamín. "La función de la memoria es proteger las impresiones del pasado. E1 recuerdo apunta a su desmembración, la memoria es conservadora, el recuerdo es destructivo." Este concepto de Benjamín adquiere una nueva dimensión porque vincula a la acción del sujeto sobre el presente histórico.

La singularidad de la memoria se funda en la acción que despierta al sujeto y moviliza el pasado, en la creación de un nuevo enunciado. Esto, que Benjamín denomina un quiebre sobre la continuidad de la historia, es fundante de la acepción productiva del recuerdo en tanto este se establece sobre un acto novedoso de cognición sobre el presente.

El pasado colectivo e individual tiene un peso relevante y puede ser soporte para pensar el porvenir. Por eso el recuerdo manifiesta una preocupación sobre el pasado pendiente, capaz de abrir una diferencia con el presente. Benjamín prolonga el ejercicio de la memoria en una acción de redención. Allí la rememoración pierde la dimensión contemplativa para afianzarse como reflexión.

Benjamín adjudicaba un valor revolucionario a las cosas anticuadas pues, en tanto poseedoras de un tiempo diferencial al presente, podían producir una eclosión en él. El coleccionista rescata objetos olvidados para incluirlos en nuevos sistemas.

En un breve texto "Desenterrar y recordar", Benjamín (2010) 350 afirma: "la memoria no es un instrumento para la exploración del pasado, sino solamente su medio" y continúa "quien intenta acercarse a su propio pasado sepultado tiene que comportarse como un hombre que excava". En este texto, el recuerdo aparece en el gesto arqueológico de la búsqueda. El recuerdo que busca prioriza el actuar del sujeto y a su vez supone la necesidad de otros para el ejercicio de la memoria.

Búsqueda y reconocimiento son también reconstrucción que permite la elaboración crítica sobre lo acontecido y restituye al sujeto y a la comunidad su capacidad de confrontación, discusión y enunciación no sólo del pasado sino de los futuros posibles. En esta discusión permanente en el espacio social, donde lo individual persiste junto a lo colectivo, aparece el aspecto dialéctico del recuerdo para evitar la totalización del relato. En esa dialéctica, el recuerdo es una formación inestable entre los intersticios de lo privado y lo público que habilita el permanente conflicto y negociación de las identidades. 


\section{Bibliografía}

Adorno, Th. (1980), Teoría estética. Madrid: Taurus.

Arendt, Hanna. Entre el pasado y el futuro, ocho ejercicios sobre la reflexión politica. Barcelona, Península, 1990.

Arendt, H. (2002), Les origines du totalitarisme. Paris: Gallimard.

Bauman, Z. (1997), De legisladores a intérpretes. Sobre la modernidad, la postmodernidad y los intelectuales. Buenos Aires: Universidad Nacional de Quilmes.

Bayardo, R. (1997), Globalización e identidad cultural. Buenos Aires: Ciccus.

Benjamin, W. (1989), La obra de arte en la época de su reproductibilidad técnica. Buenos Aires: Taurus.

Benjamin, W. (2010), "Excavar y recordar", in Imágenes que piensan. Obras. Libro IV, vol I. Madrid, Abada: 350.

Bourdieu, P. (2002), Campo de poder, campo intelectual. Montressor: Jungla simbólica.

Brecht, B. (1970), Escritos sobre teatro. Buenos Aires: Nueva Visión.

Brecht, B. (1973), El compromiso en literatura y arte. Barcelona: Península.

Deleuze, G. (2009), Ensayos sobre biopolitica, excesos de vida. Buenos Aires: Paidós.

Dubatti, J. (2012), Cien años de teatro argentino. Buenos Aires: Biblos.

Foucault, M. (1997), Hermenéutica del sujeto. La Plata: Altamira.

García Canclini, N. (2006), Culturas hibridas. Estrategias para entrar y salir de la modernidad. Sao Pablo: Edusp.

Grüner, E. (1998), Estudios culturales. Reflexiones sobre el multiculturalismo. Buenos Aires: Paidós.

Habermas, J. (1989), El discurso filosófico de la modernidad. Madrid: Taurus.

Irazábal, F. (2004), El giro politico. Buenos Aires: Biblos.

Pellettieri, O. (2004), Reflexiones sobre teatro. Buenos Aires: Galerna.

Proaño Gómez, L. (2013), Teatro y estética comunitaria, miradas desde la filosofía y la politica. Buenos Aires: Biblos.

Rancière, J. (2013), Aisthesis. Buenos Aires: Bordes Manantial.

Rancière, J. (2013), El malestar en la estética. Buenos Aires: Clave intelectual.

Rancière, J. (2015), El espectador emancipado. Buenos Aires: Ellago ediciones.

Todorov, T. (1994), Face à l'extrême, Trad: Frente al límite. Buenos Aires: Paidós.

Todorov, T. (2002), Memoria del mal. Tentación del bien. Indagación sobre el siglo 
María Inés Grimoldi

$X X$. Buenos Aires: Península.

Todorov, T. (2008), Los abusos de la memoria. Buenos Aires: Paidós.

Touraine, A. (1992), Critique de la modernité. Paris: Fayard.

Verzero, L. (2013), Teatro militante. Radicalización artística y política en los años 70. Buenos Aires: Biblos.

Zizek, S. (2004), Amor sin piedad, hacia una politica de la verdad. Buenos Aires: Síntesis. 